ISSN 1012-277X S.Afr.j.ind.eng.

$-81-$

S A Journal of Industrial Engineering, vol 5, No 2, December 1992, pp.81-89

\title{
QUALITY IN EDUCATION
}

Keith Sandrock

Division of Industrial Engineering

School of Mechanical Engineering

University of the Witwatersrand

Box 249, HITS, 2050, RSA

\section{ABSTRACT:}

This is an attempt to set out a methodology for improving quality in a university department.

OPSOMMING:

Hierdie bydrae is ' $n$ poging on 'n prosedure vir die verbetering van kwaliteit binne die departement van 'n universiteit uiteen te sit. 


\section{INTRODUCTION}

Quality in education is becoming an important issue world-wide. It is a spin-off from the current trend towards manufacturing ercellence which has swept the industrial milieu, and which is spiling over into service industries, government departments, and other non-manufacturing sectors.

Quality in education is important enough to have been allocated a track of its own at the 1990 International Conference of the American Society for Quality Control (ASOC).

Unfortunately, most of the literature available in this topic area is concerned with applications - with HOW we did it. A general wethodology has not been put forward. This paper attempts to fill shat gap - and to alert us to the impor tance of adopting such an approach if we are to continue competing successfully ith usiversities wor ld-wide.

The apolication of quality management tools and techniques (teveloped for industrial use) to the academic environment is not ifficult. Data are available, and that is all that is needed to construct statistical control charts for monitoring costs, expenditure, resource usage, academic progress, etc.

The quality principle is the same, namely to get the process into statistical control, and then having done so, to improve it.

Sut this by itself is not quite encugh. Many academic institutions have progressed along the quality route this far (to their credit certainly), but over and above the use of analytical techniques also need a comprehensive METHODOLOGY.

\section{METHODOLOGY}

A methodology is concerned with WHAT, and not with HOW.

If does not stand alone. It is centrally placed on the spectrum of science which extends from philosophy at one end to method at the other.

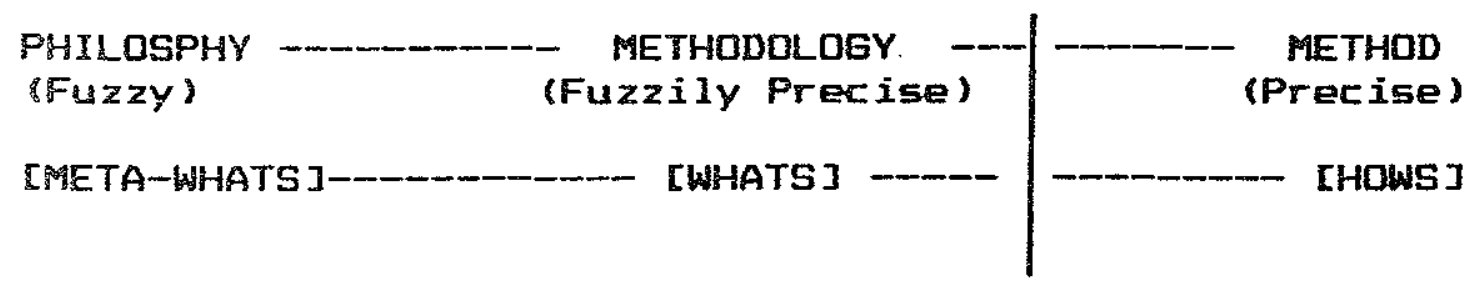

GUALITY GUIDELINES are 5 ituated about here on the spectrum. (They are neither WHATS nor HOWS, and best described as META-HOWS)

It is not possible to discuss methodology without referring to its left hand and right hand flanks on the spectrum. However, in what follows, the area of method per se (such as the use of SPC tools etc.l is glossed over, and instead space is alloted to the discussion of guidelines for methodology development and 
We will refer to guidelines as meta-hows, or simply M-Hows.

The development of a methodology is an exercise in systems thinking. We start off by asking WHAT. Every tine we ask WHAT we move upwards in the systems hierarchy to a wider-system, and every time we ask HOW we move downwards to a subsystem. Hence asking too many WHATS is a bad thing as it leads to a very ide systems boundary which will contain a number of enviromental systems that are irrelevant. So we must know wen to stop asking WHAT and to get on with some HOWS.

A fairly logical stopping point, as far as quality in the department of a university is concerned, is the totality of systems included in the boundary drawn around the department, its external customers, and the major suppliers of its resources. This boundary signifies that systems which lie beyond the external customers and the suppliers of resources constitute the enviranment.

These environmental systems include other university departments, politics, sociomeconomic systems, and cultural systems etc.

One further point which is implicit in all that follows is that everyone in the system be they students, lecturers, top management, or whatever, wears three hats named: Customer, Supplier, and Manager.

For example a lecturer may at one point in time be seen as a customer by his students who would then be wearing the hat of supplier. But at another point in time the students are customers and the lecturer is the supplier. The hat of manager is ever present because we are all continually managing our affairs and our resources. Given this situation, are we all aware of the needs of our customers, and how to supply them ith a superior product or service? Have we (as customers) informed our suppliers of our particular requirements, and how these should be met?

If we have not done these things EXPLICITLY then no time should be lost in doing so for they are the very essence of quality impravement.

But to return to the development of a methodology, starting at the external customer/supplier interface and working top-down, the systems hierarchy unfolds as follows:

WHAT NO. 1

Know the vaice of the external customers ISA Industry, Professional Societies etc.) Know a 150 the voice of the internal customers (other departments, staff, students)
HOW

Quality Function Deployment (GFD).

QFD again, modified to suit. 
WHAT NO. 2

Establish the quality of the Department's major suppliers of equipment and materials.

SHAT NO. 3

Set up a MISSION STATEMENT for the Department.
Independent supplier audit, and construction of a Supplier Quality Matrix.

By determining the minimum necessary activities for running it so as to not only meet customer requirements - - but so as to DELIGHT the customers (external and internal), while taking into account supplier quality etc. And then setting up formal human activity systems to acomplish these activities.

Set up at least the following:

* Production (education) plan

* Resource and Material Requirements Plan

- Capacity Plan

* Capital Investment Plan

* Marketing Strategy

* Education Activity Control

* Cost Contral

WHAT NO. 5

Set up a QUALITY PLAN for quality management and control, and for continuous improvement.

WHAT NO. 6

Monitor and keep pace with the competition.
Following the guidelines (MHows) of established quality experts such as Deming et al, and tailoring these guidelines to the Department's needs.

Benchmarking the competition, and using the results as feedback to the Mission Statement.

DETAILED DESCRIPTIONS OF THE "HOWS' MENTIONED ABOVE

\section{Quality Function Deployment (QFD)}

Quality Function Deployment captures customer 'wants' and 'needs' (the voice of the customer).

It is a structured process of ensuring that these customer 
requirements are accurately translated into process and service characteristics.

It enables prioritization of needs and innovative responses to them, and it coordinates implementation for naximum effect.

QFD also ensures that actions taken are based on these original customer requirements.

The OFD discipline provides us with a framework and a structured process to enhance an organization's ability to communicate; document, analyse, and prioritize its efforts.

When correctly applied, QFD enables an organization to exceed the expectations of the customer. It works best within an organization when there is strong commitment and a disciplined approach to implementation.

To explain the meaning of the phrase OFD Kogure \& Akao louality Progress June $1988 \mathrm{p} 5$ ) wrote: "In Japanese, deployment refers to an extension and broadening of activities. Thus OFD means that responsibilities for producing a quality item must be assigned to all parts of the corporation."

The idea that drives GFD is the Voice of the Custoner. The idea is to find out what the customer wats and then to use this information for product development, rather than first developing a product or service and then finding out what the customer does not like about it.

In the case of a university, GFD has a special connotation because apart from the voices of the external and internal customers we must also heed the voice of Society itself, and of Western Civilization in particular.

Western Civilization, according to George Reisman[1], is a body of knowledge and values. Its ideas entail an understanding and acceptance of the laws of logic; the concept of causality and consequently, of a universe ruled by natural laws intelligible to man; the whole known corpus of the lass of mathematics and science; the individual's self-responsibility based on his free will to chose between good and evil; the value of man above all other species on the basis of his unique possesion of the power of reason.

Thus, QFD (in academia) is not simply a free market exercise, but is subject to constraints imposed by the meta environmental systems which lie beyond the boundary discussed above, and which are the cornerstone of Western Civilization.

\section{Supplier Quality Matrix}

All major suppliers of goods and equipment should be audited as to their GUALITY of PRODUCT and QUALITY of SERVICE.

Generally the audit in these two dimensions of quality will classify suppliers from A1 (the best) through to D4 say - i.e. 16 possibilities in all. This is the system favoured by the Johannesburg Chamber of Commerce who require that the audit be conducted by an independent consultant at the suppliers expense. As well as this matrix another must be developed for the goods themselves and the variables used here are COST and CRITICALITY. 
Hence a critical high cost item is classed as A1, while minor items of stationery would be D4 items.

This classification could be conducted 'in house' by the Depar tment.

To use the system, suppliers with ratings of 82 or better are chosen for the supply of critical high cost items irrespective of whether or not they are the lowest tenderers. On the other hand the supply of C-class. and D-class items would fall to cheaper vendors with ratings in the lower right hand portion of the supp 1 ier-matrix.

Regarding 5 tudents (which from a certain viewpoint may be regarded as raw aterial), the qualifications required by the university for their admission is a form of quality control at the source, but unlike the parallel activity in industry, it does not primarily determine the quality of the final ouput. AELLY[2] points this out clearly and goes on to state that admission criferia in fact determine how hard we have to work to produce good output. He says: abviously our universities cannot take in al1 comers, but equally $I$ don't think that they can simply write theis ow cheque on society, demanding a school system which provides thes with entrants optimally trained to their specifications, so as to make the task of tertiary education as simple as possible."

Thus part of the quality challenge facing universities is to

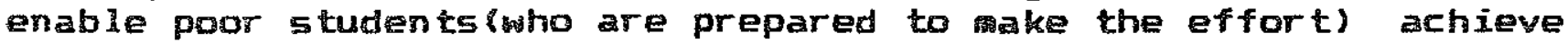
AN UNLOWERED qualification by the time they finish.

\section{Mission statement}

This is NaT a ish ist. It is a formal declaration of intent, $a$ list of objectives which are being achieved at this moment in time by dedicated human activity subsystems within the organization.

The wission statement is therefore a systems map of the organization. As such it is evolutionary, dynaic, and creative.

\section{Quality Guidelines}

A number of quality guidelines proposed by leading experts in the field are to be found in the TQC literature.

To see how these guidelines can be tailored to suit a particular organizaticn, in this case a university department, Deming's 14 points have been restructured and condensed below. The reader may wish to compare this list with the original which has been published extensively elsewhere, inter alia, Nancy Mann[3].

Deming's Points [Restructured for Academia]:

1) Create constancy of purpose in the institution.

2) Insist on statistical evidence of the quality of all the institution's operations and processes. 
3) Insist on statistical evidence of the academic ability of staff and of the ability and progress of students.

4) Examine the problems in the system, structure them, solve them, and in so doing contribute to a program of continuous improvement.

5) Eliminate numer ical (pedestrian) goals for members of staff. Eliminate standards that prescribe numerical quotas (or equivalent) and replace them with imaginative, creative, handson, statistically based incentives.

6) Replace fixed-period inspection (examination) by RANDOM evaluation of student's ability and progress.

7) Institute modern methods of tuition.

8) Improve methods of supervision of faculty and staff.

9) Break down barriers between departments in the university.

10) Remove barriers that stand between the department and its students and wich inhibit their(the students) pride of achievement.

11) Institute a vigorous program of education and development of Staff.

It must be stressed that there are many sets of guidelines for Total Guality Management.

Amongst these are the guidelines proposed by Phil Crosby, Armand Feigenbaum, and Genichi Taguchi - all of which can be restructured for academia.

\section{Monizor and Keep Pace}

Dne of the major problems that occurs in organizations is that the dynamic nature of the systems hierarchy within wich they exist is not explicitly recognized.

Stafford Beer [4] pointed out (very clearly) in an invited lecture to the British Institute of Management the fact that our models of institutions and enterprises are wildy out of date.

He said that our organizational structures are frozen out of history. "If you look at any of our big institutions, our oldest established firms, our government departments, then you will find them all structured according to something that happened in the past."

"Having this frozen structure we are naturally using the methods appropriate to that structure. But if the structure is no longer appropriate in the real world then neither are the methods."

"The situation has moved on, and so have we; the situation has repeatedly changed, and so have we. But we have enshrined the model. Therefore the lines connecting everything to the old model become more and more stretched."

"My message is this. The elastic has broken."

There is a very real message for our universities in these words. By taking a long hard quality orientated view of our institutions we will be in a position to ADAPT to the big shifts which are taking place in the environment. 


\section{SOME AMERICAN EXAMPLES}

A large section of the October 1991 edition of QUALITY PROGRESS has been alloted to the subject of Quality in Education. In a leading article in this issue Karen Bemowski (associate editor) discusses:

* Educating Mankind

* Meeting Industry:'s Needs

* Meeting Student's Needs

* Generating Know ledge

* ASQC (American Society for Quality Control) involvement in quality in higher education

Bemowski refers to universities which are using TQM to improve their quality. These include:

University of Miami

University of Chicago

Calumbia University

Dregon State University

Nor th Dakota State University

Leading the way is the Fox Valley Technical College which has a quality process built on the following four elements:

- Education and training of all FVTC employees

* Process, product, and service improvement throughout the organization

* Use of measurement tools to identify poor quality

- Management accountability for quality

At present educators in the USA are developing a supplement for ISO 9000 standards especially aimed at academic institutions, and in addition they are considering an award patterned on the Baldrige Astard.

The improvement of American schooling is also receiving a great deal of attention because:

- The dropout rate in public high schools is $25 \%$

- The USA ranked 13 th (out of 13 participating nations) on average high school achievement scores

* 25 illion Americans are functionally illiterate

On April 181991 President Bush unveiled "AMERICA 2000: An Education Strategy" which is basically a 15-point action package [QUALITY PRDGRESS October 1991 page 46]. Amongst the 15 points are:

* The development of a nation-wide achievement test program

- Freedom of school choice [no more bussing etc.]

* Teacher and principal certification

* Teacher recognition and reward for achievement

President Bush's plan is a national strategy and not a Federal program. Thus it relies on everyone for success - Federal Governement, State Government, business, parents, and educators. 
High schools which have already implemented quality programs inc lude :

* Mt. Edgecombe High School, Sitka, Alaska, started quality improvement in 1988

* Crawford Central School District, Meadville, Pennsylvania

* George Westinghouse Vocational and Technical High School, Brooklyn, New York, which started to think about quality in 1987 based on Deming's principles, and which has the following mission 5 tatement:

The purpose of George Westinghouse Vocational and Technical High School is to provide quality vocational, technical, and acadenic educational programs that will maximize each student's full potential in today's changing technological society and prepare students to meet the challenges of our rapidly changing world. In an era of intense international competition, each student will be prepared to meet the demands of the world of work, pursue post-secondary education, and address ife's challenges.

\section{CONCLUSION}

Robin Plumbridge, Chief Executive officer of Goldfields, pointed out at the opening of new facilities donated to wits University on 7 May 1991 that this University can no longer afford to give anybody on the staff a free ride. Everyone must be cost effective and quality conscious if the organization is to survive the $1990^{\circ} 5$.

He says we need to adopt the 'CRQ' strategy which is helping the country"s mining companies survive the present crises. CRO stands for COST, RELEVANCE, QUALITY.

Whatever we do, whatever we buy, whatever decisions we make - the underlying criteria for strategic choice must be COST, RELEVANCE, and QUALITY(in all its forms).

This is a WHAT of course - it tells us what ought to be doing. In this paper other similar WHATS are proposed, as well as the HOWS for achieving them.

\section{REFERENCES}

[1] REISMAN G, 1991 . Professor of Economics, Peperdine University, Los Angeles. Extract from a recent lecture given at the University of Denver

[2] RELLY G, 1991. Chancellor of Rhodes University - Extract from his inaugural address of April 121991.

[3] MANN N, 1989. "The Keys to Excellence", Mercury Business Boaks, London.

[4] BEER S, 1975. "Platform for Change", Wiley. 